\title{
Muatan Pendidikan Lingkungan dalam Tayangan Jalan Sesama
}

\author{
BUDIMAN DAN MUHSINATUN SIASAH \\ Universitas Negeri Yogyakarta \\ lelakibudiman@gmail.com,muhsinsiasah@gmail.com
}

\begin{abstract}
Abstrak
Penelitian ini bertujuan untuk mendapatkan media pendidikan lingkungan di luar sekolah dalam rangka meningkatkan kepedulian lingkungan pada anak-anak.Penelitian ini merupakan penelitian analisis isi, objek penelitian adalah 10 tayangan Jalan Sesama yang ditayangkan selama Maret-April 2010.Penelitian ini dilakukan dengan menghitung frekuensi kemunculan pesan pendidikan lingkungan dalam setiap episode.Instrumen yang digunakan dalam penelitian ini adalah lembar koding.Data yang terkumpul dianalisis dengan membandingkan data hasil koding dari tiga orang pengkoding yang berbeda.Hasil penelitian menunjukkan bahwa pesan pendidikan lingkungan yaitu pengenalan flora dan dan fauna adalah pesan yang paling sering muncul, seba nyak $73,01 \%$. Pesan tersebut paling sering muncul dalam segmen studio, yaitu sebanyak 38,67\%. Pesan pendidikan lingkungan dalama tayangan Jalan Sesama lebih banyak disampaikan secara implisit dan menyatu dalam alur cerita, yaitu sebanyak 66,04\%. Pesan-pesan pendidikan lingkungan sebagian besar disampaikan oleh tokoh pembantu, yaitu sebanyak 87,75\%.
\end{abstract}

Kata Kunci: pendidikan lingkungan hidup, anak-anak, televisi, Jalan Sesama.

\begin{abstract}
This research aims to get environmental education media of informal education in order to improve children's environment concern. This research is a content analysis research. The object of this research is 10 episodes of Jalan Sesama which were aired during March-April 2010. The research was conducted by calculating the frequency of the emergence of environmental education messages. The instrument used in this research is the coding sheet. The collected data were analyzed by comparing three coding results. The finding of the research indicates that environmental education messages in the form of the introduction to flora and fauna is the content that appears with highest frequency (73.01\%). The messages are often delivered in studio segment (38.67\%). The messages of environmental education in Jalan Sesama are mostly presented implicity and cohesively in the story (66.04\%). The messages are delivered mostly by the secondary characters (87.75\%).
\end{abstract}

Keywords: environmental education, children, television, Jalan Sesama. 


\section{PENDAHULUAN}

Kriteria kualitas SDM yang diperlukan saat ini bukan hanya unggul dalam penguasaan ilmu dan teknologi semata.Kearifan dalam menggunakan sumber daya alam juga diperlukan, mengingat kerusakan lingku ngan saat ini sudah sangat mengkhawatirkan.Kearifan seseorang dalam pengelolaan lingkungan sebagai sumber daya untuk pembangunan bukan terjadi dengan seketika, tetapi memerlukan suatu proses pendidikan. Untuk menunjang hal tersebut, muncul gagasan untuk menerapkan suatu pendidikan lingkungan di sekolah-sekolah melalui jalur formal, maupun di luar sekolah melalui jalur informal (di dalam keluarga dan kehidupan sehari-hari dalam masyarakat).

Sehubungan dengan hal itu, pelaksanaan Pendidikan Lingkungan Hidup (PLH) dalam pendidikan formal diatur melalui Kesepakatan Bersama Antara Menteri Nega ra Lingkungan Hidup dengan Menteri Pendidikan Nasional. Berdasar kesepakatan tersebut,pelaksanaan Pendidikan Lingkungan Hidup dilakukan terintegrasi dengan mata pelajaran yang telah ada.Melalui PLH, diharapkan siswa sadar untuk memelihara dan melestarikan sumber daya alam. Kesadaran dan kepedulian lingkungan hidup yang diintegrasikan dalam setiap mata pelajaran di sekolah diharapkan membentuk perilaku siswa dalam kehidupan sehari-hari.

Selama ini, pelaksanaan PLH di sekolah masih mengalami berbagai macam permasalahan. Dalam laporan penelitian yang berjudul 'Mapping Climate Education in Indonesia: Opportunities for Development', Putrawidjaja, peneliti dari British Council, mengungkapkan, bahwa meskipun sudah ada pendidikan lingkungan hidup di sekolah, tetapi belum banyak yang memanfaatkannya dengan baik. Pendidikan lingkungan hidup masih dianggap sebagai beban atau pelajaran tambahan di beberapa sekolah (Kompas, 12 Agustus 2009).

Permasalahan lainnya adalah materi PLH lebih banyak bersifat teoritis dan kurang memasukkan hal-hal praktis dari kehidupan sehari-hari. Soemarwoto (2001, p.180-183) menyatakan bahwa pendidikan lingkungan hidup perlu ditinjau kembali. Menurutnya, selama ini pelajaran lingkungan hidup cenderung pada pengajaran ekologi dan tidak memasukkan hal-hal praktis dari kehidupan sehari-hari. Kendala lainnya adalah belum adanya konsep dasar PLH yang baku serta kurangnya komitmen pelaku pendidikan dalam pelaksanaan pendidikan lingkungan hidup.

Selain melalui kurikulum di sekolah, pendidikan lingkungan hendaknya juga dilakukan di lingkungan keluarga. Pendidikan yang paling efektif adalah keteladanan dari orangtua, dan pembiasaan pola hidup yang bersih, sehat, dan ramah lingkungan dalam keluarga. Selain dengan keteladanan, orangtua dapat memberikan pengetahuan lingkungan hi dup kepada anak dengan mengikuti program tayangan televisi. Adegan visual yang di tampilkan dalam sebuah tayangan akan lebih diingat dan ditiru oleh anak-anak. Penelitian Gerbner (1992) yang melahirkan teori kultivasi menyebutkan bahwa anak-anak meniru apa yang dilihatnya, baik dalam keseharian maupun dalam media massa. Media berpe ran dalam membentuk sebagian dari kepri badian anak-anak. Artinya, televisi ideal dijadikan sebagai salah satu media pembelajaran bagi anak-anak.

Penelitian yang dilakukan oleh Zamris Habib, dkk. (2001), dengan judul Film Anakanak di TV dan Pengembangan Program Pendidikan Budi Pekerti (Jurnal Teknodik No. 9/V/Teknodik/Oktober/2001), menunjukkan bahwa terdapat muatan pendidikan budi pekerti dalam film anak-anak yang ditayangkan di televisi. Sementara itu berdasar penelitian oleh John Hopkins Bloomberg School of Public Health (2010), Sesame Street Program Improves DevelopmentFor Children In Indonesia (International Journal of Behavioral Development, December 5, 2010), menunjukkan bahwa anak-anak yang diarahkan untuk menyaksikan Jalan Sesama secara signifikan meningkat dalam keaksaraan, matematika, keterampilan kognitif awal, pengetahuan, dan kesadaran keselamatan sosial dibandingkan dengan mereka yang tidak atau kurang diarahkan ke tayangan tersebut. 
Penelitian lain yang relevan dengan penelitian ini adalah penelitian dengan judul Hubungan Terpaan Media Televisi dengan Belajar Kognitif Pada Anak (Kasus: Sekolah Dasar Negeri 04 Dramaga, Bogor, Jawa Barat) (Skripsi DepartemenSains Komunikasi dan Pengembangan Masyarakat, Fakultas Ekologi Manusia, Institut Pertanian Bogor) yang dilakukan oleh Viora Toriza (2010). Hasil penelitian menunjukan terpaan media televisi pada anak cukup tinggi namun belajar kognitifnya rendah. Anak-anak umumnya menonton televisi lebih dari lima jam per hari, anak cenderung menonton televisisekedar memenuhi kebutuhan akan hiburan, bukan untuk memenuhi kebutuhan kognitif.

Sedangkan dalam tesisyang diajukan kepada Faculty of The College of Communication Of Ohio University, penelitian Stephanie Anne Hay (2003)dengan judul "Sesame Street" and the Media: The Environments, Frames and Representations Contributing to Success, dihasilkan temuan bahwa tayangan Sesame Street berbeda dari program televisi anak-anak lainnya. Program anak-anak lain pada umumnya berkualitas rendah, memberikan efek negatif, mengandung kekerasan, dan banyak mengandung pesan komersial.

Hasil penelitian yang dilakukan oleh Mahallisa Dyah Pristanti (2011), Pemanfaatan Media Rekaman Televisi untuk Meningkatkan Aktivitas dan Hasil Belajar Siswa Kelas III di SDN Kiduldalem 2 Malang Pada Mata Pelajaran IPS (Skripsi Universitas Negeri Malang) menunjukkan bahwa: a) pembelajaran de ngan memanfaatkan media rekaman televisi sangat efektif digunakan dalam kegiatan pembelajaran pada mata pelajaran IPS; b) siswa yang belajar dengan media rekaman televisi, memiliki aktivitas yang sangat baik dibandingkan sebelum belajar dengan memanfaatkan media rekaman televisi; c) hasil belajar siswa setelah belajar dengan media rekaman televisi juga ikut meningkat.

Berdasarkan survei kepemirsaan TV AGB Nielsen (AGB Nilesen Newsletter Edisi 20, April 2008) di 10 kota, dua puluh satu persen (21\%) penonton televisi adalah anak-anak berusia 5-14 tahun. Menonton televisi sudah menjadi praktik rutin dalam kehidupan sehari-hari (everyday life culture), hampir setiap hari anak-anak memiliki waktu sen diri untuk menonton program televisi. Hasil penelitian yang dilakukan oleh YPMA (Yayasan Pengembangan Media Anak) pada 2006 terhadap 939 anak dari 5 Sekolah Dasar di Jakarta dan Bandung menunjukkan bahwa anak-anak menonton televisi 3,5 jam sehari pada hari biasa dan 5 jam sehari pada hari Iibur. Riset lain yang dilakukan oleh $A G B$ Nielsen selama periode Januari-Maret 2008, anak-anak menghabiskan rata-rata 3 jam untuk menonton TV dalam sehari.

Dari berbagai pilihan program anak yang ditayangkan di stasiun televisi ternyata tidak semuanya aman untuk anak-anak. Berdasarkan temuan dari Komisi Penyiaran Indonesia dan sejumlah penelitian menunjukkan, tidak sedikit acara televisi khusus anak yang mengandung unsur kekerasan dan seksual sehingga tidak pantas dikonsumsi anak (Kompas, 14 Juli 2008). Yayasan Pengembangan Media Anak menegaskan bahwa tayangan anak yang masuk dalam kategori aman adalah tayangan yang memberikan manfaat lebih, seperti muatan pendidikan, dapat dapat memotivasi anak untuk berprestasi dan menjadi yang terbaik, mengembangkan sikap percaya diri anak, serta serta berisi penanaman nilai-nilai moral dalam kehidupan. Nilai-nilai yang sering ditampilkan di antaranya adalah persahabatan, dan penghargaan terhadap orang lain. Beberapa contoh tayangan kategori aman ini antara lain Surat Sahabat, After School, Jalan Sesama, Buku Harian si Unyil, Si Bolang, dan dan Dora The Explorer (Kidia, Mei 2008).

Program Jalan Sesama termasuk salah satu program terbaik dan paling banyak ditonton. Dalam rilis rating publik berdasarkan penelitian yang dilakukan Yayasan SET tahun 2009, program Jalan Sesama masuk dalam program televisi terbaik dengan persentase pemirsa 2,5\% - 3,5\%. Jalan Sesama tidak hanya masuk kategori program terbaik, tetapi juga mendapat rating tinggi untuk acara anak-anak, yakni 1,6 dengan share sebesar 11,7 .

Berdasarkan alasan di atas, peneliti tertarik untuk meneliti bagaimana muatan pen- 
didikan lingkungan dalam tayangan Jalan Sesama.

Tujuan dari penelitian ini adalah untuk mendapatkan media pendidikan lingkungan di luar sekolah dalam rangka meningkatkan kepedulian lingkungan pada anak-anak.Hasil dari penelitian ini diharapkan memberi manfaat praktis bagi orang tua, yaitu mendorong pendidikan melek media bagi orang tua, dan mendorong para orang tua untuk memanfaatkan televisi sebagai media pembelajaran di rumah. Manfaat penelitian ini bagi guru, diharapkan lebih mendorong pemanfaatan televisi sebagai media pembelajaran di dalam kelas, juga memberikan alternatif pilihan media pembelajaran pendidikan lingkungan hidup. Sedangkan manfaat teoritis dari penelitian ini diharapkan memberi kontribusi khasanah ilmu pengetahuan khususnya di bidang Pendidikan Ilmu Pengetahuan Sosial.

\section{METODE}

Penelitian ini merupakan penelitian anali sis isi dengan pendekatan kualititatif.Analisis isi sebagai sebuah alat riset digunakan untuk menyimpulkan kata atau konsep yang tampak di dalam teks atau rangkaian teks. Pene liti melakukan kuantifikasi dan menganalisis teks dan mengambil kesimpulan mengenai pesan yang terdapat di dalam teks.

Populasipenelitian ini adalah tayangan Jalan Sesama musim tayang kedua yang ditayangkan Trans 7 selama tahun 2010 seba nyak 52 episode. Sampel dalam penelitian ini dipilih secara acak menggunakan metode purposive sampling, didasarkan pada alasan bahwa episode yang menjadi sampel penelitian mudah didapatkan rekamannya. Sepuluh episode tayangan Jalan Sesama yang menjadi sampel penelitian adalah sebagai berikut:
Tabel episode yang menjadi sampel penelitian

\begin{tabular}{cc}
\hline Tayangan & Episode \\
\hline 1 & 19 Maret 2010 \\
2 & 22Maret 2010 \\
3 & 12 April 2010 \\
4 & 13 April 2010 \\
5 & 20 April 2010 \\
6 & 22 April 2010 \\
7 & 23 April 2010 \\
8 & 26 April 2010 \\
9 & 5 Mei 2010 \\
10 & 6 Mei 2010 \\
\hline
\end{tabular}

Data dikumpulkan dari tayangan yang sudah ditentukan sebelumnya. Pene liti dibantu dua orang pengkoding lain. Peneliti dan pengkoding menonton taya ngan per episode yang telah ditentukan sebelumnya. Masingmasing pengkoding mencatat hasil penelitian dalam lembar koding yang telah dibuat.

Keseluruhan rekaman tayangan Jalan Sesama dianalisa melaluimetode kuantitatif dengan teknik analisis isi. Data dianalisa dengan menggunakan lembar koding (coding sheet) yang dibuat berdasarkan unit analisis dan kategori yang sudah ditetapkan.

Dalam melakukan koding data, peneliti dibantu dua orang pengkoding lain. Peneliti dan pengkoding menonton rekaman taya ngan Jalan Sesama, kemudian mengisi hasilnya di lembar koding.

Hasil dari masing-masing penilaian di lembar koding dimasukkan ke dalam sebuah tabel besar. Dari hasil penelitian ini akan diketahui frekuensi masing-masing kategori muatan pendidikan lingkungan hidup dalam tayangan Jalan Sesama dan diperoleh data kuantitatif.Data kuantitatif tersebut diinterpretasikan oleh peneliti, untuk menjawab pertanyaan penelitian dan mengambil ke simpulan. 
Unit Analisis Isi

\begin{tabular}{|c|c|c|}
\hline No & Unit Analisis & Kategori \\
\hline \multirow[t]{6}{*}{1} & Pesan & Membuang sampah pada tempatnya \\
\hline & & Menanam pohon \\
\hline & & Mengenal jenis flora dan fauna \\
\hline & & Menghemat energi \\
\hline & & Menyayangi binatang \\
\hline & & Merawat tanaman \\
\hline \multirow[t]{3}{*}{2} & Segmen & Segmen studio \\
\hline & & Segmen LAF \\
\hline & & Segmen animasi \\
\hline \multirow[t]{2}{*}{3} & Sifatpesan & Eksplisit \\
\hline & & Implisit \\
\hline \multirow[t]{2}{*}{4} & Penyampai pesan & Peran utama \\
\hline & & Peran pembantu \\
\hline
\end{tabular}

\section{HASIL DAN PEMBAHASAN}

Program Jalan Sesama merupakan salah satu program televisi hiburan dan pendidikan anak-anak yang diadaptasi dari serial internasional Sesame Street. Program yang diproduksi bersama oleh PT. CreativeIndigo Production dan Sesame Workshop, sebagai pemilik lisensi Sesame Street, ini ditujukan untuk anak-anak usia 3-6 tahun. Jalan Sesama bertujuan untuk membantu anak-anak Indonesia belajar pengetahuan dasar dan ketrampilan hidup selain merujuk pada isuisu tertentu dari suatu daerah sepertimemotivasi anak untuk melindungi lingkungan dan menghargai perbedaan yang merupakan bagian dari hidup keseharian mereka.

\section{Pesan Pendidikan Lingkungan}

Pesan pendidikan lingkungan diteliti dengan menghitung frekuensi pesan tertentu pada setiap episodenya. Hasil penelitian unit analisis pesan pendidikan lingkungan disajikan dalam tabel berikut ini:

Tabel 1. Hasil Penelitian Unit Analisis Pesan Pendidikan Lingkungan

\begin{tabular}{|c|c|c|c|c|c|c|c|c|}
\hline Bulan & & & & & & & & \\
\hline Pesan & $\mathbf{F}$ & $\%$ & $\mathbf{F}$ & $\%$ & $\mathbf{F}$ & $\%$ & $\mathbf{F}$ & $\%$ \\
\hline $\begin{array}{l}\text { Membuang } \\
\text { sampah pada } \\
\text { tempatnya }\end{array}$ & 1 & 50 & - & - & - & - & 1 & 1,6 \\
\hline Menanam pohon & & & 9 & 18 & & & 9 & 14,3 \\
\hline $\begin{array}{l}\text { Mengenal jenis } \\
\text { flora dan fauna }\end{array}$ & 1 & 50 & 34 & 68 & 11 & 100 & 46 & 73 \\
\hline $\begin{array}{l}\text { Menyayangi } \\
\text { binatang }\end{array}$ & - & - & 1 & 2 & - & - & 1 & 1,6 \\
\hline Merawat tanaman & - & - & 6 & 12 & - & - & 6 & 9,5 \\
\hline Jumlah & 2 & 100 & 50 & 100 & 11 & 100 & 63 & 100 \\
\hline
\end{tabular}


Dari data yang diperoleh selama bulan Maret-April 2010, frekuensi menunjukkan bahwa pesan untuk mengenal jenis flora dan fauna adalah pesan yang kemunculannya pa ling sering dibandingkan dengan tema yang lain. Pesan pendidikan lingkungan untuk mengenal jenis flora dan fauna muncul sebanyak 34 kali dalam 6 episode selama bulan April.

Hal ini menunjukkan bahwa pesan tersebut oleh produser dianggap yang paling menarik untuk ditayangkan dan diterima de ngan baik oleh penonton. Pesan ini dianggap menarik sehingga memiliki frekuensi pena yangan yang tinggi karena flora dan fauna lebih mudah diterima dan disukai anak-anak, dibandingkan pesan lain. Sesuai dengan kultur masyarakat Indonesia, pengenalan flora dan fauna juga merupakan pelajaran yang sering diberikan sejak dini baik oleh orangtua maupun guru di sekolah.

Segmen

Unit analisis segmen diteliti dengan menghitung frekuensi kemunculan pesan pada tiap segmen tayangan setiap episodenya. Hasil penelitian unit analisis segmen disajikan dalam tabel berikut ini:

Tabel 2.Hasil Penelitian Unit Analisis Segmen

\begin{tabular}{lrrrrrrrrr}
\hline Bulan & \multicolumn{2}{c}{ Maret } & \multicolumn{2}{c}{ April } & \multicolumn{2}{c}{ Mei } & \multicolumn{2}{c}{ Jumlah } \\
\hline Segmen & F & & \multicolumn{1}{c}{ \% } & \multicolumn{1}{l}{ F } & \% & F & \% & F & \% \\
Studio & 1 & 50 & 26 & 42,6 & 2 & 29,4 & 29 & 38,6 \\
LAF & - & - & 16 & 26,2 & 3 & 17,7 & 19 & 25,4 \\
Animasi & 1 & 50 & 19 & 31,2 & 7 & 52,9 & 27 & 39 \\
Jumlah & $\mathbf{2}$ & $\mathbf{1 0 0}$ & $\mathbf{6 1}$ & $\mathbf{1 0 0}$ & $\mathbf{1 2}$ & $\mathbf{1 0 0}$ & $\mathbf{7 5}$ & $\mathbf{1 0 0}$ \\
\hline
\end{tabular}

Dari tabel tersebut terlihat bahwa dari keseluruhan data yang diperoleh selama bulan Maret-Mei 2010 menunjukkan bahwa pesan pendidikan lingkungan selalu muncul di segmen studio, yaitu sebanyak 26 kali (42,62\%) dalam 6 episode selama bulan April. Segmen studio merupakan tayangan inti Jalan Se sama, karena dalam segmen ini tokoh utama muncul dan durasi tayang yang paling lama dibandingkan segmen lainnya.

Sebagai media yang bersifat audio visual, bagian inti sebuah program televisi selalu menjadi fokus perhatian pemirsa. Televisi sebagai sebuah media yang bersifat audio visual, mampu menghadirkan kejadian, peristiwa, atau khayalan yang tidak terjangkau panca indera anak-anak. Anak-anak mampu mengingat $50 \%$ dari apa yang mereka lihat dan dengar meskipun ditayangkan sekilas di televisi.

Pesan pendidikan lingkungan yang selalu muncul pada bagian utama tayangan Jalan Sesama, menunjukkan bahwa pesan tersebut sengaja diletakkan oleh pembuat program di segmen studio, yang menjadi inti taya ngan, untuk lebih menarik perhatian pemirsa, dalam hal ini anak-anak.

Tayangan Jalan Sesama merupakan sebuah tayangan dengan tokoh utama empat boneka bernama Jabrik, Momon, Putri, dan Tantan. Penggunaan studio dalam ruang menjadi alasan utama agar tokoh-tokoh tersebut lebih mudah dimainkan sesuai jalan cerita masing-masing episode. Hal ini berkaitan dengan sifat media televisi dapat menyajikan pesan/objek yang sebenarnya termasuk hasil dramatisir secara audio visual dan unsur gerak (live) dalam waktu bersamaan (broadcast). Pesan yang dihasilkan televisi dapat menyerupai benda/objek yang sebenarnya atau menimbulkan kesan lain. 
Sifat Pesan

Analisis sifat pesan diteliti dengan menghitung frekuensi sifat pesan secara implisit dan eksplisit setiap episodenya. Hasil penelitian unit analisis sifat pesan disajikan dalam tabel berikut ini:

Tabel 3. Hasil Penelitian Unit Analisis Sifat Pesan

\begin{tabular}{lcrrrrrrr}
\hline \multicolumn{1}{c}{ Bulan } & Maret & \multicolumn{3}{c}{ April } & \multicolumn{2}{c}{ Mei } & \multicolumn{2}{c}{ Jumlah } \\
\hline Sifat Pesan & F & \% & F & \% & F & $\mathbf{\%}$ & F & \% \\
Eksplisit & - & - & 12 & 33,3 & 6 & 40 & 18 & 33,96 \\
Implisit & 2 & 100 & 24 & 66,7 & 9 & 60 & 35 & 66,04 \\
Jumlah & $\mathbf{2}$ & $\mathbf{1 0 0}$ & $\mathbf{3 6}$ & $\mathbf{1 0 0}$ & $\mathbf{1 5}$ & $\mathbf{1 0 0}$ & $\mathbf{5 3}$ & $\mathbf{1 0 0}$ \\
\hline
\end{tabular}

Pesan pendidikan lingkungan dalam ta yangan Jalan Sesama lebih banyak disampaikan secara implisit. Penyampaian pesan yang bersifat implisit ini sebagaimana diakui oleh Produser Jalan Sesama, Putri Rahartana, bahwa penyampaian pesan pendidikan lewat alur cerita yang akrab dengan anak-anak menjadi kekuatan program Jalan Sesama. Setiap episode Jalan Sesama dibentuk dalam satu tema yang berkesinambungan, sehingga semuanya dapat terangkum dan dipahami dengan baik oleh anak-anak walaupun tiap episode menyajikan beberapa cerita sekaligus.

Hal ini berkaitan dengan beberapa sifat anak yang akan diapaparkan sebagai berikut. Pertama, anak sulit membedakan mana yang baik atau buruk serta mana yang pan- tas ditiru atau diabaikan. Kedua, anak tak memiliki self-censorship dan belum memiliki batasan nilai. Ketiga, sebagai penonton, anak bersifat pasif dan tidak kritis. Pesan-pesan edukatif baik dalam aspek kognitif, afektif, ataupun psikomotorik, akan lebih mudah diterima anak-anak jika disampaikan secara implisit dalam sebuah program televisi.

\section{Penyampai Pesan Cerita}

Unit analisis penyampai pesan cerita diteliti dengan menghitung apakah peran utama ataukah peran pembantu sebagai penyampai pesan pendidikan lingkungan dalam setiap episode. Hasil penelitian unit analisis penyampai pesan cerita disajikan dalam tabel berikut ini:

Tabel 4. Hasil Penelitian Unit Analisis PenyampaiPesan Cerita

\begin{tabular}{lccrcrrrrr}
\hline Bulan & \multicolumn{2}{c}{ Maret } & \multicolumn{2}{c}{ April } & \multicolumn{2}{c}{ Mei } & \multicolumn{2}{c}{ Jumlah } \\
\hline $\begin{array}{l}\text { Penyampai } \\
\text { Pesan }\end{array}$ & F & \% & F & \% & F & \% & F & \% \\
Peran Utama & 1 & 33,33 & 5 & 14,29 & - & - & 6 & 12,25 \\
Peran & 2 & 67,67 & 30 & 85,71 & 11 & 100 & 43 & 87,75 \\
Pembantu & & & & & & & & \\
Jumlah & $\mathbf{3}$ & $\mathbf{1 0 0}$ & $\mathbf{3 5}$ & $\mathbf{1 0 0}$ & $\mathbf{1}$ & $\mathbf{1 0 0}$ & $\mathbf{4 9}$ & $\mathbf{1 0 0}$ \\
\hline
\end{tabular}


Dari keseluruhan episode Jalan Sesama yang diteliti, frekuensi penyampai pesan pendidikan lingkungan adalah pemeran utama (Momon, Putri, Tantan, dan Jabrik) sebanyak $57,15 \%$. Hal ini dikarenakan tokoh-tokoh tersebut adalah tokoh utama yang sudah dikenal oleh anak-anak. Peran utama dalam Jalan Se sama adalah tokoh-tokoh yang mendapat perhatian utama pemirsa. Tokoh utama menjadi daya tarik utama dari sebuah tayangan untuk menyampaikan pesan.

Daya tarik menjadi salah satu faktor penentu keberhasilan komunikasi. Penerima pesan akan mengikuti pandangan pengirim pesan yang memiliki daya tarik. Sebaliknya, jika pengirim pesan tidak memiliki daya tarik, maka penerima pesan tidak akan mengacuhkannya, sehingga pesan yang disampaikan akan berlalu begitu saja. Pemeran utama sebuah taya ngan televisi adalah daya tarik bagi pemirsanya.

Pesan yang paling sering muncul dalam tayangan Jalan Sesama adalah pe ngenalan jenis flora dan fauna. Pesan ini selalu muncul dalam setiap episode Jalan Sesama. Dari dua episode di bulan Maret, peneliti menemukan bahwa terdapat pesan mengenai pengenalan jenis flora dan fauna. Pada episode tanggal 19 Maret 2010 terdapat adegan Pak Dalang, Momon, dan Jabrik pergi ke pantai. Adegan di pantai tersebut mengenalkan anak-anak kepada bintang laut, kerang, dan pohon kelapa. Penggambaran pantai dalam episode ini sesuai dengan pendapat Hamalik (dalam Darwanto, 2007, p.124-125) berpendapat bahwa penggunaan televisi sebagai media pembelajaran di sekolah mempunyai manfaat sebagai berikut: (1) televisi bersifat langsung dan nyata; (2) televisi memperluas tinjauan kelas; (3) televisi dapat menciptakan kembali semua peristiwa yang lalu; (4) televisi dapat menunjukkan banyak hal dan segi; (5) televisi menarik minat bukan saja bagi anak-anak tetapi juga orang dewasa; (6) televisi mampu memberi bantuan pada guru; (7) televisi mampu membawa sumber-sumber yang ada di masyarakat ke dalam kelas

Sedangkan pada episode tanggal 22 Maret 2010, pengenalan flora dan fauna pengenalan flora dan fauna divisualkan oleh berbagai tanaman hias, perdu, dan tumbuhan keras yang ada di pemukiman lengkap dengan berbagai binatang antara lain anjing, ayam, keledai, dan domba. Hal ini sesuai yang diungkapkan oleh Effendy (1993, p.3-30) menyatakan bahwa dengan menonton televisi, pemirsa se olah-olah melihat dan mendengar sendiri peristiwa yang terjadi di suatu tempat.

Pada bulan April 2010, dari sebanyak 6 (enam) tayangan yang menjadi sampel, pesan pengenalan flora dan fauna juga ada dalam setiap episodenya. Misalnya, pada episode tanggal 20 April 2010, segmen life action film di episode ini juga menghadirkan Elmo dan Leony seba gai bintang tamu. Mereka berdua pergi ke kebun anggrek. Elmo akhirnya tahu bahwa warna dan motif bunga anggrek bermacam-macam, bahkan ada anggrek bermotif tutul seperti macan. Dalam segmen ini anak-anak diajak untuk mengenal flora, yaitu bunga anggrek.

Pesan pendidikan lingkungan lainnya juga muncul pada episode 22 April dalam adegan ketika Tantan, Puteri, Momon, dan Pak Bagus memperhatikan sekumpulan burung yang melakukan migrasi. Salah satu burung dari kelompok migrasi memisahkan diri dari kelompoknya dan mendarat di rumah Tantan. Burung bernama Buri bercerita bahwa mereka bermigrasi karena suhu dingin di tempat asal, sehingga harus mencari tempat yang hangat karena kelelahan. Buri menumpang istrirahat di rumah Tantan.

Demikian juga dari 2 (dua) episode selama bulan Mei 2010, pesan pengenalan flora dan fauna juga muncul dalam tiap episodenya. Pada episode tanggal 6 Mei 2010, pesan pendidikan lingkungan muncul dalam adegan ketika Elmo dan Aming (bintang tamu) berdiri di depan kandang burung merak. Mereka membicarakan tentang betapa indahnya bulu yang dimiliki burung merak dan menarikan tarian burung merak.

Sedangkan nilai pendidikan lingku ngan lainnya, yaitu membuang sampah, menanam pohon, merawat tanaman, dan menyayangi binatang, tidak selalu muncul di setiap episodenya. Pesan untuk membuang sampah muncul dalam adegan Pendekar Badak Muda 
yang membantu Ki Sanak menyapu halamannya. Pesan menanam pohon dan merawat tanaman muncul antara lain pada tanggal 13 April 2010, dalam adegan warga Jalan Sesama membersihkan lingkungan sekitar. Pesan tersebut secara implisit muncul dalam adegan Tantan, Momon, serta Pak dan Bu Bagus melihat poster lomba lingkungan hijau di papan pengumuman. Sedangkan secara eksplisit, terdapat dalam adegan Bapak dan $\mathrm{Bu}$ Bagus menyiram tanaman dan merawat tanaman.

Hal ini sesuai konsep pendidikan lingkungan hidup yang digagas dalam Konferensi Perserikatan Internasional Perlindungan Alam dan Sumberdaya Alam (International Union for Conservation of Nature and Nature Resources) sebagai berikut:

Environmental education is a process of recognizing values and clarifying concept in order to develop the skills and attitudes that are necessary to understand and appreciate the interrelations among man, his culture and his biophysical surrounding. Environmental education is also entails practice in decision-making, and the self-formulation of code of behavior about the issues concerning environmental quality.

Berdasarkan batasan tersebut, terlihat bahwa pendidikan lingkungan hidup merupakan proses pengenalan kembali nilainilai dan penjelasan konsep-konsep untuk mengembangkan keterampilan dan sikap yang bermakna untuk mengerti dan menghargai hubungan timbal balik di antara se sama manusia dengan kebudayaan dan lingkungan fisis biologisnya.

Frekuensi kemunculan pesan pengenalan flora dan fauna ini sesuai dengan pendapat Hurlock (1997, p.343) yang menyebutkan bahwa anak prasekolah menyukai acara-acara yang menampilkan kehidupan binatang, film-film kartun dan acara musik, serta acara komedi. Frekuensi kemunculan pesan pengenalan flora dan fauna tersebut sesuai dengan pendapat Nasution (dalam Deddy Mulyana \& Idy Subandi Ibrahim, 1997, p.205-206) bahwa televisi jika dikonsumsi secara benar akan menghasilkan sejumlah manfaat bagi anak untuk membantu memahami dunia sekitar.
Dengan sebuah tayangan televisi anak-anak bisa memenuhi keingintahuan mereka tentang segala sesuatu di sekitar mereka baik yang dekat maupun yang jauh.

Pesan pendidikan lingkungan dalam tayangan Jalan Sesama selalu muncul di bagian inti tayangan. Bagian inti tayangan Jalan Sesama merupakan bagian di mana seluruh tokoh utama muncul. Tokoh utama merupakan daya tarik bagi pemirsa anak-anak. Se perti yang dikemukakan oleh Hurlock bahwa anak-anak cenderung lebih fokus dan perhatian terhadap sebuah acara ketika tokoh utama yang menjadi idolanya muncul. Menurut Hurlock, tokoh televisi memberi model untuk berbagai peran dalam kehidupan, perilaku yang sesuai dengan jenis kelamin dan karier.

Penyampai pesan pendidikan lingkungan dalam tayangan Jalan Sesama adalah tokohtokoh pembantu seperti Pak Bagus dan Pak Dalang. Hal ini bisa dipahami karena tokoh utama dalam tayangan ini berupa karakter boneka yang masih kanak-kanak. Dengan penyampai pesan tokoh-tokoh pembantu bukan tak berarti pesan pendidikan tak diterima dengan baik oleh pemirsa. Pesan pendidikan lingkungan masuk ke dalam cerita meski disampaikan secara eksplisit.

Hurlock menyatakan bahwa anak suka meniru, mereka merasa bahwa apa saja yang disajikan dalam acara televisi tentunya merupakan cara yang dapat diterima baginya dalam bersikap sehari-hari. Jika tokoh-tokoh utama tersebut menyampaikan pesan pendidikan, anak-anak juga akan menirukan apa yang dilakukan sang tokoh dalam tayangan tersebut. Teori kultivasi menyebutkan bahwa anak-anak akan berpeluang meniru apa yang dilihatnya, baik dalam keseharian maupun dalam media massa. Media berperan dalam membentuk sebagian dari kepribadian anakanak. Jika media televisi secara gamblang menyajikan adegan-adegan visual dalam program untuk anak-anak, maka dari situlah pada mulanya anak-anak melakukan proses peniruan.

Proses peniruan semakin terjadi jika anak-anak tergolong sebagai penonton kelas berat (heavy viewer). Dalam teori kultivasi, penonton kelas berat merupakan penonton 
yang memiliki intensitas menonton lebih tinggi dibandingkan penonton lainnya dalam satu komunitas. Penonton kelas berat akan menganggap apa yang ditampilkan televisi mirip dengan realitas yang terjadi dalam kehidupan sehari-hari.

Jika seorang anak tergolong penonton kelas berat, maka televisi dapat memberi pengaruh berkelanjutan atau jangka panjang. Layaknya analogi zaman es (ice age analogy) dalam teori kultivasi, terpaan televisi yang dinikmati terus-menerus akan memberi dampak besar di kemudian hari. Apa yang ditampilkan oleh layar televisi akan terus tertanam dalam benak anak-anak dan akhirnya semakin melanggengkan proses peniruan. Jadi, selain frekuensi gambar yang sama dan berulang-ulang, intensitas menonton juga dapat memengaruhi proses peniruan. Pesan eksplisit pendidikan lingkungan dalam tayangan Jalan Sesama dibuat menyatu bersama alur cerita, sehingga membuat anak-anak lebih betah menyaksikan acara tersebut. Misalnya, pada episode tanggal 22 April 2010 dalam adegan ketika Tantan, Puteri, Momon, dan Pak Bagus memperhatikan sekumpulan burung yang melakukan migrasi dan melewati Jalan Sesama di Beranda Rumah Tantan. Salah satu burung dari kelompok migrasi memisahkan diri dari kelompoknya dan mendarat di rumah Tantan. Burung bernama Buri itu menceritakan bahwa mereka bermigrasi karena tempat asalnya sedang dingin suhunya, sehingga kelompoknya berpindah mencari tempat yang hangat.

Adegan Buri menceritakan proses migrasi tersebut, sesuai pendapat Nasution bahwa memperluas wawasan/membukakan cakrawala. Televisi mampu "menjelaskan" segala sesuatu yang tidak mungkin dijelaskan oleh orang tua secara lisan. Darwanto (2007, p. 45-46) menyatakan bahwa sifat televisi yang bersifat audiovisual sangat membantu pemirsa untuk cepat mengerti dan mencernakan pesan yang diterimanya.

Pesan pendidikan lingkungan yaitu pesan untuk merawat tanaman antara lain muncul pada episode 26 April 2010. Pada episode tersebut, anak-anak mendapatkan pesan untuk selalu menjaga lingkungan dengan tidak menebang pohon sembarangan melalui cerita Pak Dalang. Sebagaimana yang dikemukakan oleh Laswell (Darwanto, 2007:32) bahwa salah satu fungsi media massa adalah the transmission of the social heritage from one generation to the next, artinya media massa sebagai sarana untuk menyampaikan nilai dan warisan sosial budaya dari satu generasi ke generasi yang lain. Umumnya, secara sederhana fungsi media massa ini dimaksudkan sebagai fungsi pendidikan (educational function of mass media).

Dengan penyampaian pesan secara eksplisit dan implisit, pesan pendidikan lingkungan dalam tayangan Jalan Sesama sesuai dengan salah satu tujuan umum pendidikan lingkungan hidup menurut konferensi Tbilisi 1997, yaitu untuk menciptakan pola perilaku yang baru pada individu, kelompok, dan masyarakat sebagai suatu keseluruhan terhadap lingkungan (Gyallay, 200, p.409). Lebih lanjut, Gyallay mengemukakan bahwa tujuan dalam pendidikan lingkungan meliputi aspek: (1) pengetahuan; (2) keterampilan; (3) kesadaran; (4) sikap; dan (5) partisipasi.

Pesan pendidikan lingkungan yang di sampaikan secara eskplisit dan implisit tersebut menguatkan pendapat Hardjoko (1994, p.4) bahwa media televisi juga merupakan wahana yang kuat sekali pengaruhnya dalam pembentukan pola pikir, sikap, dan tingkah laku selain menambah pengetahuan dan memperluas wawasan masyarakat. Pendapat senada dikemukakan oleh Widarto (1994, p.7) yang menyatakan bahwa siaran televisi memiliki daya penetrasi yang sangat kuat terhadap kehidupan manusia sehingga mampu merubah sikap, pendapat, dan perilaku seseorang dalam rentang waktu yang relatif singkat.

Dengan penyampaian pesan secara eksplisit dan implisit, diharapkan anak-anak lebih sadar dan peka terhadap lingkungan sekitar. Hal ini sejalan dengan misi utama pendidikan IPS adalah untuk membantu siswa belajar tentang masyarakat dunia di mana mereka hidup dan memperoleh jalan, belajar menerima realitas sosial, mengembangkan pengetahuan, serta sikap dan 
ketrampilan untuk membantu mengasah pencerahan manusia.

Tujuan tersebut seperti yang dikemukakan oleh Chapin (dalam Sapriya, 2007: 10) yaitu pertama, membina pengetahuan siswa tentang pengalaman manusia dalam kehidupan bermasyarakat pada masa lalu, sekarang, dan di masa yang akan datang; kedua, menolong siswa untuk mengembangkan ke terampilan (skill) untuk mencari dan mengolah/memproses informasi; ketiga, menolong siswa untuk mengembangkan nilai/sikap (value) demokrasi dalam kehidupan bermasyarakat; keempat, menyediakan kesempatan kepada siswa untuk mengambil bagian/ berperan serta dalam kehidupan sosial.

Tidak hanya memuat pesan pendidikan lingkungan yang merupakan ranah kognitif, tayangan Jalan Sesama juga memuat pesan afektif dan psikomotorik. Pesan afektif antara lain muncul dalam segmen Agen Rahasia 123. Dalam menyelesaikan misinya, Agen Rahasia 123 selalu mendapat bantuan dari seseorang. Selesai mendapat bantuan, Agen Rahasia selalu mengucapkan terima kasih.

Sedangkan ranah psikomotorik, antara lain muncul ketika Momon dan Jabrik mengikuti petunjuk dalam peta harta karun (Episode 19 Maret 2010). Petunjuk dalam peta tersebut mengharuskan Momon dan Jabrik melompat sebanyak tiga kali. Pesan lainnya muncul pada adegan Momon dan Jabrik yang berlatih bermain drum menggunakan tong bekas bersama Gilang Ramadhan.

Hal ini sesuai dengan pendapat yang dikemukakan Fraenkel (1980, p.8-11) yang menyatakan ada empat kategori tujuan IPS, yaitu pengetahuan, keterampilan, sikap, dan nilai. Pengetahuan diartikan sebagai kemahiran dan pemahaman terhadap sejumlah informasi dan ide-ide untuk membantu siswa belajar lebih banyak tentang dirinya, fisiknya, dan dunia sosial. Keterampilan diartikan sebagai pengembangan berbagai kemampuan tertentu untuk mempergunakan pengetahuan yang diperolehnya.

Pesan pendidikan lingkungan yang terdapat dalam tayangan Jalan Sesama sesuai dengan apa yang dikemukakan oleh Nasution (dalam Deddy Mulyana\&IdySubandi Ibrahim,
1997: 205-206), yang mengemukakan bahwa jika televisi dikonsumsi secara benar, maka akan menghasilkan sejumlah manfaat bagi anak. Manfaat-manfaat tersebut antara lain: (1) Membantu memahami dunia sekitar; (2) Anak-anak bisa memenuhi keingintahuan mereka tentang segala sesuatu di sekitar, baik yang dekat maupun yang jauh; (3) Membantu proses belajar baca tulis dan melek visual (visual literacy); (4) Dengan sifat televisi yang audiovisual, anak-anak akan terbiasa dengan penampilan visual dari benda-benda yang telah dan belum mereka kenal; (5) Memperluas wawasan/ membuka cakrawala; (6) Televisi mampu "menjelaskan" segala sesuatu yang tidak mungkin dijelaskan oleh orangtua secara lisan; (7) Memperkaya pengalaman hidup; (8) Televisi memungkinkan anak untuk mengalami berbagai hal dan mengunjungi berbagai tempat secara tidak langsung; (9) Menunjang pelajaran sekolah terutama dalam pengetahuan umum. Banyak muatan acara televisi yang bisa menjadi penunjang dan pengayaan (enrichment) bagi pengetahuan yang diperoleh di kelas; (10) Memberikan "sambungan" dengan dunia global. Melalui televisi, anak dapat merasakan ketersambungannya dengan bagian yang lebih luas dari lingkungan sekitar.

Hal ini memperkuat pendapat Brown (1977:347) yang menyatakan bahwa fungsi edukasi media televisi lebih optimal diban dingkan jenis media massa lain karena sifat khas yang dimiliki oleh media itu sendiri. Sesuai dengan fungsinya, televisi sangat memungkinkan untuk dimanfaatkan sebagai media pendidikan, karena dapat memberikan rangsangan, membawa serta, memicu, membangkitkan, memengaruhi seseorang untuk melakukan sesuatu, memberikan saran-saran, memberikan warna, mengajar, menghibur, memperkuat, menggiatkan, menyampaikan pengaruh dari orang lain, memperkenalkan berbagai identitas (ciri) sesuatu, memberikan contoh, proses internalisasi tingkah laku, berbagai bentuk partisipasi serta penyesuaian diri, dan lain-lain.

Proses pembelajaran pada hakikatnya merupakan proses komunikasi. Dalam suatu 
proses komunikasi selalu melibatkan tiga komponen pokok, yaitu komponen pengirim pesan (guru), komponen penerima pesan (siswa), dan komponen pesan itu sen diri yang biasanya berupa materi pelajaran. Kadang-kadang dalam proses pembelajaran terjadi kegagalan komunikasi. Pemanfaatan televisi sebagai media pembelajaran diharapkan bisa mengatasi masalah tersebut. Brown (1977) mengungkapkan, televisi mampu memberikan rangsangan, membawa serta, memicu, membangkitkan, dan memengaruhi seseorang untuk melakukan sesuatu, memberikan saransaran, memberikan warna, mengajar, menghibur, memperkuat, menyampaikan pengaruh dari orang lain, memperkenalkan berbagai identitas atau ciri sesuatu, memberikan contoh, proses internalisasi tingkah laku, berbagai bentuk partisipasi, penyesuaian diri, dan lain-lain.

\section{SIMPULAN}

Simpulan dari penelitian ini adalah pesan pendidikan lingkungan yang paling sering muncul dalam tayangan Jalan Sesama adalah pesan mengenai pengenalan jenis flora dan fauna $(73,01 \%)$. Pesan pendidikan lingku ngan selalu muncul di bagian inti tayangan yaitu di segmen studio $(38,67 \%)$, disampaikan secara implisit dan menyatu bersama alur cerita dalam setiap episode $(66,04 \%)$. Pesan pendidikan lingkungan dalam taya ngan Jalan Sesama lebih banyak disampaikan oleh tokoh pembantu $(87,75 \%)$.

Hinggasaatinipemanfaatanmediatelevisi, sebagai sarana penunjang pembelajaran di kelas belum banyak dilakukan oleh guruguru SD. Banyak film anak-anak di televisi yang dapat dimanfaatkan sebagai media pembelajaran yang menarik. Televisi mampu memberikan rangsangan, membawa serta, memicu, membangkitkan, memengaruhi se seorang untuk melakukan sesuatu, memberikan saran-saran, memberikan warna, mengajar, menghibur, memperkuat, menggiatkan, menyampaikan pengaruh dari orang lain, serta memperkenalkan berbagai identitas atau ciri sesuatu sehingga dapat meningkatkan minat dan motivasi siswa (Brown, 1977, p.347).
Selain itu, media televisi memiliki pe ngaruh kuat dalam pembentukan pola pikir, sikap, dan tingkah laku juga menambah pe ngetahuan dan memperluas wawasan masyarakat. Oleh karena itu, peran orangtua sangat penting untuk mendampingi anak menonton televisi, karena program televisi akan berpengaruh pada kejiwaan anak yang cende rung meniru atau mencoba apa yang dilihatnya. Media televisi mempunyai peran besar dalam mendidik dan memengaruhi perkembangan jiwa anak sehingga dapat dimanfaatkan sebagai sarana pembelajaran. Akan tetapi, pemanfaatan media ini untuk kepen tingan pengajaran sebaiknya memperhatikan kriteri-kriteria sebagai berikut: (1) Ketepatan dengan tujuan pengajaran, artinya media pengajaran dipilih atas dasar tujuan-tujuan instruksional yang telah ditetapkan; (2) Dukungan terhadap isi bahan pelajaran; artinya bahan pelajaran yang sifatnya fakta, prinsip, konsep, dan generalisasi sangat memerlukan bantuan media agar lebih mudah dipahami siswa; (3) Kemudahan memperoleh media; artinya media yang diperlukan mudah diperoleh oleh guru pada waktu mengajar; (4) Keterampilan guru dalam menggunakanya; apapun jenis media yang diperlukan syarat utama adalah guru yang dapat mengguna kanya dalam proses pengajaran; (5) Tersedia waktu untuk menggunakannya; sehingga media tersebut dapat bermanfaat bagi siswa selama pengajaran berlangsung; (6) Sesuai dengan taraf berpikir siswa; memilih media untuk pendidikan dan pengajaran harus sesuai dengan taraf berpikir siswa, sehingga makna yang terkandung di dalamnya dapat dipahami para siswa (Sudjana, 2002:4-5).

Melalui pemanfaatan televisi sebagai media pembelajaran di dalam kelas, siswa akan lebih terangsang untuk belajar, apalagi jika yang ditayangkan adalah film yang disukai anak-anak.

Setelah melakukan serangkaian penelitian, peneliti merumuskan beberapa saran yang dapat menjadi masukan bagi pihak-pihak yang terkait dengan dunia pendidikan: (1) Orangtuadapatmemanfaatkan program televisi, terutama Program JalanSesama, seba gai media pembelajaran pendidikan lingku 
ngan bagi anak-anak di rumah; (2) Orangtua harus lebih cermat dalam memilihkan taya ngan televisi yang boleh ditonton oleh anak; (3) Orangtua harus selalu mendampi ngi anaks etiap kali menonton televisi sehingga mereka dapat segera memberikan penjelasan kepada anak jika ada tayangan yang tidak baik; (4) Pihak sekolah, terutama pihak guru, dapat menjadikan program televisi sebagai media pembelajaran pendidikanl ingkungan hidup dalam kegiatan belajarmengajar di kelas; (5) Sosialiasi penggunaan media pembelajaran bersifat audio visual seperti televisi bisa dimulai dari lembaga pendidikan tenaga pendidikan; (6) Penelitian selanjutnya diharapkan menggunakan mix methode dengan memadukan penelitian kuantitatif dan kualitatif sehingga didapatkan hasil yang lebihkomprehensif.

\section{UCAPAN TERIMA KASIH}

Dalam penulisan artikel jurnal ini, penulis sangat dibantu oleh banyak pihak khususnya dosen pembimbing. Untuk itu, dalam kesempatan ini penulis menyampaikan terima kasih kepada yang terhormat Pembimbing tesis, yang telah banyak membantu, mengarahkan dan membimbing sehingga artikel jurnal ini dapat terselesaikan.

\section{DAFTAR PUSTAKA}

Brown, J. R. 1976. Children And Television. Beverly Hills. California : Sage Publication, Inc.

Darwanto. 2007. Televisi Sebagai Media Pendidikan. Yogyakarta: Pustaka Pelajar.

Depdiknas. 2003. Undang-Undang RI No. 20, Tahun 2003, tentang Sistem Pendidikan Nasional.

Fraenkel, Jack R. 1980. Helping Students Think Value Strategies For Teaching Social Studies. New Jersey: Prentice-Hall.

Guntarto, B. 2002. Kajian Anak Dan Media Di Televisi. Jakarta: Yayasan Kesejahteraan Anak Indonesia.

Gyallay, Peter. 2004. Environment: PAP-ETAP Reference Guide Book, Chapter 13. Diambil pada tanggal 10 September 2009 dari http//www.un.org.kh/fae/pdfs/ section4/chapterxxx3/33.pdf.

Habib, Z. et. al. "Penelitian Film Anak-Anak Di
TV Dalam Rangka PengembanganProgram PendidikanBudi Pekerti", Jurnal Teknodik vol.9/Oktober 2001.

Hines et al. 1993. Global Issues and Environment Education. Diakses pada tanggal 7 September 2009 dari http//www.eriese. org/erie/digest/digest-05/html.

Hurlock, Elizabeth B. 1997. Perkembangan Anak(Jilid 1).(Terjemahan Meitasari Tjandrasa \& Muslichah Zarkasih). Jakarta: Erlangga. (Buku asli diterbitkan 1978).

Kementerian Negara Lingkungan Hidup. 1997. Undang-undang RI No. 23, Tahun 1997 Tentang Pengelolaan Lingkungan Hidup.

Kementerian Negara Lingkungan Hidup. (2004). Kebijakan Pendidikan Lingkungan Hidup. Jakarta.

Morrisan. 2005. Media Penyiaran: Strategi Mengelola Radio dan Televisi. Tangerang : Ramdina Prakarsa.

Mulyana, Deddy \& Ibrahim, I.S (ed). 1997. Bercinta dengan Televisi. Bandung: PT Remaja Rosda Karya.

Perin, D.G. 1977. Instructional Television : Synopsis ofTelevision in Education. New Jersey: Educational Technology Publication.

Rakhmat, J. 2004. Psikologi Komunikasi. Bandung: PT. Remaja Rosda Karya.

Sapriya. 2011. Pendidikan IPS konsep dan pembelajaran. Bandung: PT Remaja Rosdakarya.

Schram, Wilbur. ,Lyle, Jack. \& Parker, Edwin B. 1961. Television in the lives of our Children. Standford, California: Standford University Press.

Schramm, Wilbur. 1984. Media Besar Media Kecil. Semarang : IKIP Semarang Press.

Suprapti, W.1994. Pendayagunaan Siaran Televisi untuk Pendidikan Sumber Daya Manusia. Makalah Bahan Seminar Lokakarya Nasional Teknologi Pendidikan Tentang : Media Massa Elektronik dan Pendidikan Sumber Daya Manusia di Jakarta.

Waruwu, F. Tayangan Kekerasan di TV dan Dampaknya pada Anak dalam S.D. Gunarsa (Ed.), Dari Anak Sampai Usia Lanjut: Bunga Rampai Psikologi Perkembangan. Jakarta:Gunung Mulia.

Wirodono, S. 2006. Matikan TV-mu. Yogyakarta: Resist Book. 